\title{
DECONSTRUCTING THE COLONIALITY OF THE WEST-CENTRIC DEMOCRATIC IMAGINARY
}

\author{
(Desconstruindo a colonialidade do imaginário democrático centrado no Ocidente)
}

(Deconstruyendo el lado colonial del imaginario democratico Oeste-centrico)

\author{
Olga Baysha ${ }^{1}$ \\ National Research University "Higher School of Economics"
}

\begin{abstract}
Many CDA scholars assume there is an inherent opposition between democratization with its advances toward social justice and neoliberal marketization with its array of negative consequences. Analyzing the discourse of democratization in the context of contemporary Ukraine, this paper argues that the issue is more complicated. Neoliberal marketization can go hand-in-hand with the discourse of universal democratization, which only contributes therefore to the perpetuation of neocolonial injustice as manifested in ongoing neoliberal projects.
\end{abstract}

Keywords: Critical Discourse Analysis. Democratization. Neoliberalism. Neocolonialism. Ukraine.

\section{RESUMO}

Muitos estudiosos de Análise Crítica do Discurso assumem que há uma oposição inerente entre democratização, com seus avanços em direção à justiça social, e mercantilização neoliberal, com sua gama de consequências negativas. Analisando o discurso da democratização no contexto da Ucrânia contemporânea, este artigo argumenta que a questão é mais complicada. A mercantilização neoliberal pode andar de mãos dadas com o discurso da democratização universal, o que apenas contribui, portanto, para a perpetuação da injustiça neocolonial, tal como ela se manifesta nos projetos neoliberais em andamento

Palavras-chave: Análise Crítica do Discurso. Democratização. Neoliberalismo. Neocolonialismo. Ucrânia.

\section{RESUMEN}

Muchos académicos del ACD asumen que existe una oposición inherente entre la democratización, con sus avances hacia la justicia social, y la mercantilización neoliberal, con sus consecuencias negativas. Por medio del análisis el discurso de la democratización en el contexto de la Ucrania contemporánea, este artículo argumenta que la cuestión es más compleja. La mercantilización neoliberal puede ir de la mano del discurso de la democratización universal, y por lo tanto contribuye a la perpetuación de la injusticia neocolonial, como se manifiesta en los proyectos neoliberales contemporáneos.

Palabras clave: Análisis crítico del discurso. Democratización. Neoliberalismo Neocolonialismo. Ucrania.

Recebido em: março 2020

Aceito em: junho 2020

DOI: $10.26512 /$ les.v21i1.30389

\footnotetext{
${ }^{1}$ Olga Baysha is an Associate Professor at the National Research University "Higher School of Economics," Moscow, Russia. Olga Baysha earned her MS in Journalism from Colorado State University and PhD in Communication from the University of Colorado at Boulder. Olga Baysha is the author of two books, "The mythologies of capitalism and the end of the Soviet project" and "Miscommunicating social change: lessons from Russia and Ukraine. ORCID: 0000-0001-9135-9665, email: obaysha@ hse.ru.
} 


\section{INTRODUCTION}

Although there is no consensus on the definition of discourse or how to analyze it, many scholars engaged in discourse studies agree that any linguistic representation of material reality is not objective truth but a product of discursive categorizations, all of which are historically and culturally specific, and thus contingent. What distinguishes critical discourse analysis (CDA) from other subdivisions of discourse studies with which it shares the above-mentioned assumption is that CDA explicitly aims to contribute to social change along the lines of more equal power relations in communication processes and society in general. It intends to generate critical social research that would contribute to the eradication of injustice and inequality in society. As Phillips and Jørgensen put it, "The aim of critical discourse analysis as explanatory critique is to promote more egalitarian and liberal discourses and thereby to further democratization" (PHILLIPS; JØRGENSEN, 2002, p. 88).

When arguing that CDA should promote democratization, scholars usually do not question the historical and cultural specificity of "democracy," which emerged through specific developments in the Western world; rather, they rely on an ahistorical, universal "democracy" as a normative yardstick for measuring all kinds of injustices and inequalities in our contemporary globalized world. Some CDA scholars explicitly acknowledge that their critique "is based on ethical principles such as democratic norms..." (WODAK; MEYER, 2015, p. 56) and assert that "critical discourse analysis should... adopt a democratic attitude" (JÄGER; MAIER, 2015, p. 121). Others valorize democracy implicitly by arguing, for example, that "the aim [of anti-racist groups] is to fight racism and [their] norms and values feature equality, justice, democracy and so on" (VAN DIJK, 2015, p. 77), or that the global spread of neoliberalism is a "social wrong" that impoverishes people, annihilates nature, and "undermines democracy" (FAIRCLOUGH, 2015a, p. 98). Neoliberalism brings injustice, democracy brings justice; therefore, social justice can be established by defeating neoliberalism through democratization - this reasoning has become a normalized judgement for many scholars working within the paradigm of critical discourse studies, including myself in some cases (e.g. BAYSHA, 2018a; BRUCE, 2015; GUARDINO, 2018; JUSKA; WOOLFSON, 2017; POWER et al., 2016). As I strive to show in this paper, the uncritical application of the discourse of democratization to the problems of the contemporary globalized world not only contradicts the basic premise of discourse studies as outlined above, but also contributes to the perpetuation of neocolonial injustice 
as manifested in the global neoliberal order, which is sanctioned (at least partially) by the discourse of universal democratization.

In what follows, I explicate my point by (1) using critical-discourse theorizing by Norman Fairclough as an example of CDA applying West-centered democratic discourse to the issues of global neoliberalization, (2) substantiating my analysis through the example of the neoliberalization of contemporary Ukraine, and (3) drawing on the criticism of West-centered political discourse by postcolonial and decolonial scholars.

\section{DEMOCRATIZATION, NEOLIBERALISM, AND FAIRCLOUGH'S THEORIZING}

Fairclough divides his own work into three main periods according to the focus of his research at the time: (1) Critique of ideological discourse and its role in the reproduction of the statusquo associated with post-war Fordism and the "welfare state"; (2) Critique of discourse as a part of social change associated with the shift towards neoliberalism; and (3) Critique of discourse in political debate and policymaking associated with financial and economic crisis (FAIRCLOUGH, 2015b, p. 2). Because I am interested in the nexus of the discourses of democratization and neoliberalization, I will focus on the works of Fairclough's second period, which starts with the 1992 publication of Discourse and Social Change (FAIRCLOUGH, 2015b, p. 2).

In this work, Fairclough argues that "democratization in discourse, like democratization more generally, has been a major parameter of change in recent decades" and examines the question of "how real or how cosmetic changes have been" (FAIRCLOUGH, 1992, p. 201). In keeping with his findings that "overt power markers become less evident" (FAIRCLOUGH, 1992, p. 203), Fairclough suggests that the relationship between democratization and commodification may be "more complex" than simple opposition because "commodification actually implies democratization" (FAIRCLOUGH, 1992, p. 219). Three years later, he makes a similar observation in his Media Discourse, stating that "the communication style of broadcasting lies at the intersection of these democratizing, legitimizing and marketizing pressures" (FAIRCLOUGH, 1995, p. 149). "Democratization" in these early works is defined in terms of "a move towards conversational discourse" (FAIRCLOUGH, 1992, p. 219), "tendency towards informality" (FAIRCLOUGH, 1992, p. 204), and other features of "communication style" (FAIRCLOUGH, 1995, p. 148). At this point, although he acknowledges ongoing inequality in power relations, Fairclough considers "the elimination of overt markers of hierarchy" a feature of "democratization" (FAIRCLOUGH, 1992). 
In the later work of his "neoliberal period," Fairclough shifts his conceptualization of "democracy" to connect it with the notion of the "public sphere" and thus examine "power behind discourse rather than just the power in discourse": "how people with power shape "the order of discourse' as well as the social order in general, versus how people with power control what happens in specific interactions such as interviews" (FAIRCLOUGH, 2015b, p. 3). Fairclough, at this point, begins to argue that "restructured"/neoliberal capitalism has been "eroding democracy and the public sphere" (FAIRCLOUGH, 2003, p. 79), as a result of which there is "less democracy" (FAIRCLOUGH, 2003, p. 203) in the neoliberal era than before its onset. Discussing "the crisis - of the public sphere" (FAIRCLOUGH, 2013, p. 393), he puts forward the following question: "Is it possible ... to reconstruct the public sphere under contemporary social conditions?" (FAIRCLOUGH, 2013, p. 394). Linking "the debasement of democracy to the debasement of the public sphere," he sees "the reconstruction of democracy as hinging upon the reconstruction of the public sphere" (FAIRCLOUGH, 2013, p. 394). "Democracy," as conceptualized in this supposedly "debased" condition is linked to such signifiers "insecurity," "poverty," "environmental degradation" (FAIRCLOUGH, 2003, p. 203) and so forth. This new chain of equivalence linking democracy to the negative consequences of neoliberalization - a global development whose effects cannot be circumvented by national borders - expands Fairclough's analysis to a global scale.

If approached from a global/supranational perspective, however, both the earlier and later conceptualizations of "democracy" employed by Fairclough appear problematic. The signifiers "crisis," "debasement," and "erosion/eroded" (see above) suggest that before the emergence of "the formidable structural obstacles" (FAIRCLOUGH, 2013, p. 393) which Fairclough associates with "the new global form of capitalism and its ideology of neoliberalism" (FAIRCLOUGH, 2013, p. 394), there was a better - "non-debased"/"non-eroded," or at least acceptable - democratic condition that now needs to be "reconstructed." This implicit assumption does not hold if applied globally: Nowhere near all the countries in the world could boast of a democratic system of government before the advent of neoliberalism, especially if evaluated by the quality of the democratic process rather than by the mere presence of formal democratic procedures. Therefore, neither the claim made by Fairclough in 1992 that "democratization in discourse, like democratization more generally, has been a major parameter of change in recent decades" (FAIRCLOUGH, 1992, p. 201) nor his later assertion that "the restructuring of capitalism is eroding democracy and the public sphere" (FAIRCLOUGH, 2003, p. 79) can be applied globally for exactly the same reason - "democracy" has never been a common 
global condition, and therefore the advent of neoliberalism could not have "eroded" it on a global scale.

Obviously, the object of Fairclough's analysis was not the whole world but only the rather small part of it that had a historical chance to enjoy democratization and then witnessed the deterioration of its condition. However, nowhere in his writing related to neoliberalism does Fairclough discuss the limitations of his analysis by questioning the extent to which it can be applied to the whole world, as increasingly incorporated into the global neoliberal project. Even when discussing Romania's neoliberal "transition to a market economy and western parliamentary democracy" as "a dialectical process of external "colonization"” (FAIRCLOUGH, 2013, p. 464), Fairclough does not problematize "western parliamentary democracy" as part of the equation, focusing instead on the negative aspects of a free market, trade liberalization, and so forth. From my perspective, this lack of attention to the West-centered specificity by which CDA places democracy at the heart of its normative judgment has an ideological implication, albeit an unintended one. By implicitly presenting democracy as a universal condition, critical scholars inadvertently contribute to the naturalization of the discourse of democratization, which, as a result, becomes a "common sense" of the modern condition, another of its "no alternative" dogmas, and an instrument of neoliberal colonization, as I argue in the following section.

Before going on, however, I would like to acknowledge that in his analysis of global neoliberal discourses, Fairclough does mention the current historical nexus between "democracy" and "neoliberalism." When discussing "globalism" as a specific discourse representing globalization in reductive neoliberal economic terms (FAIRCLOUGH, 2006, p. 34), Fairclough agrees with Steger's (2005) observation that one of globalism's main promises is that "globalization furthers the spread of democracy in the world" (FAIRCLOUGH, 2006, p. 34). When discussing the case of Romania, he also problematizes the “relation of equivalence... textured between 'democracy' and '(the institutions of) the state of right"' (FAIRCLOUGH, 2013, p. 516), where the social obligations of "the state of right" are interpreted in neoliberal terms. In these and similar cases, Fairclough comes very close to the problem of the established nexus between the discourses of democratization and neoliberalization, but stops short of considering the following questions:

(1) What role does the discourse of democratization play in the global spread of neoliberalism presented as a "normal" historical development?

(2) Has the global expansion of neoliberalism been bolstered and propagated by the discourse of democratization imagined to be a universal norm? 
(3) What are the discursive conditions of possibility for the emergence of the nexus between "democracy" and "neoliberalism," which have come to be equivalentially united?

These were the questions I had in mind when taking up this project.

\section{CONTEXT AND METHODOLOGY}

\subsection{Context}

When the Soviet Union collapsed in the early 1990s, its population learned the lessons of Western-style "neoliberal democratization" the hard way. From the very beginning, the radical neoliberal transformation of the country's hitherto socialist economy went hand-in-hand with the discourse of democratization; as the signifier "democracy" stood in for the signifier "capitalism," the latter was rendered invisible or unimportant (BAYSHA, 2014). The simplification of the historical narrative and its presentation as a mythical fight between democratic good and non-democratic evil played a crucial role in the transformation of the signifier "democracy" into a tool for neoliberalization that brought enormous suffering to the populations of post-Soviet states (STIGLITZ, 2003).

But the neoliberalization of post-Soviet states under the veil of "democratization" did not end in the 1990s. In 2014, after the victory of its Euromaidan revolution, Ukraine started another round of neoliberal transformations. Under the supervision of the IMF and other supranational institutions, the country has been undergoing painful neoliberal reforms characterized by the privatization of the health care system, slashing of social benefits, reductions to state financing of education and culture, and the dismantling of other remnants of the socialist order that Ukraine had preserved since Soviet times (BOYD-BARRETT, 2017). Under the terms of a loan from the World Bank and IMF, Ukraine has been opened to genetically modified crops and seeds. It was urged to deregulate the use of agricultural lands, promote the sale of arable lands to foreign investors, cut regulations on food and plant production, and reduce corporate taxes and custom duties (YURCHENKO, 2018). Needless to say, none of these neoliberal interventions brought prosperity to the majority of Ukrainians. By 2015, Ukraine's economy was “one of the worst performing in the world" (YURCHENKO, 2018, p. 9), with the Ukrainian Hryvnia (national currency) losing about $70 \%$ of its value against the U.S. dollar from 2014 to 2015.

When discussing the economic collapse of the post-Euromaidan Ukraine, many observers tend to focus on the destructive role of Russia's interference in Ukrainian affairs, particularly its 
annexation of Crimea and provision of support in the war in the East of Ukraine. However, what is often lost in representing the Ukrainian crisis exclusively through this frame is that conflict between Russia and the West over Ukraine has also, to a large extent, been a result of ongoing attempts by the West to bring Ukraine into its economic zone of influence (SAKWA, 2015). As Yurchenko puts it, the "abysmal performance" of Ukraine's economy after the Maidan "is rather a testimony of the expansion of transnational capitalist imperialism" (2018, p. 10). In other words, the whole conflict and its tragic developments have their roots in the contradictions within the global neoliberal order, but these connections are usually masked by the mythological narrative of a "battle of civilizations" between democracy and autocracy.

\subsection{Text Analyzed}

In the next section, analyzing the Joint Declaration of the Eastern Partnership Summit that took place in Vilnius on November 28-29, 2013, I show how the discourse of democratization legitimizes and masks the neoliberal agenda of the EU's policy towards Ukraine. From an abundance of similar documents furthering the agenda of neoliberalization-as-democratization, I have chosen this declaration because it was the Vilnius Summit that marked the beginning of the Maidan revolution, with all its catastrophic consequences for Ukraine: Euromaidan protests became widespread after then-President Viktor Yanukovych, representing Ukraine at the summit, refused to sign the Association Agreement with the EU on the grounds that it would have detrimental consequences for Ukraine's economy ${ }^{2}$.

\subsection{Method of Analysis}

\footnotetext{
${ }^{2}$ The Association Agreement with the European Union was an extension of the European Neighborhood Policy (ENP) project launched by the EU in 2004 with an idea of creating a comfort zone around the Union - "a ring of friends" that would be aligned with the West though without necessarily becoming EU members. In May 2008, the Eastern Partnership (EaP) initiative was launched targeting six post-Soviet states - Armenia, Azerbaijan, Belarus, Georgia, Moldova, and Ukraine. The program aimed to improve political and economic relations with these states by encouraging them to implement reforms toward the principles of rule of law, a market economy, and good democratic governance. Each of these six countries was expected to sign an individual Association Agreement (AA) with a provision of deepening bilateral economic relations through a "Deep and Comprehensive Free Trade Area" (DCFTA).
} 
In my analysis of the Vilnius Declaration, I employ two analytical methods. The first is informed by Ernesto Laclau's theory of hegemonic discourse; the second is immanent critique as conceptualized by Norman Fairclough.

According to Laclau, a hegemonic discourse is formed when a signifier acquires a hegemonic position whereby it represents an entire set of other signifiers united equivalentially. By assuming this hegemonic function, however, the particular term loses much of its specificity and "becomes something on the order of an empty signifier, its own particularity embodying an unachievable fullness" (LACLAU, 2005, p. 71). Insisting on the tropological character of any articulation, Laclau asserts that "hegemony means the passage from metonymy to metaphor, from a 'contiguous' starting point to its consolidation in 'analogy"' (LACLAU, 2014, p. 22). The culmination of this tropological movement is the moment of synecdoche, when one particular sector represents the new collective identity - when a part stands in for the whole. Using this conceptualization of hegemonic discourse, I analyze in the next section how "democracy" comes to represent synecdochically other elements that have been united equivalentially, and thus assumes a hegemonic position.

In my critique of the "democratic discourse" of the Declaration, I also draw on Fairclough's conceptualization of "immanent critique" as a normative critique of discourse that is opposed to “transcendental critique” (FAIRCLOUGH, 2006, p. 12). According to Fairclough, immanent critique "identifies internal contradictions within the social reality, including those between what is supposed or said to happen and what actually does happen" (FAIRCLOUGH, 2006, p. 12). In other words, immanent critique enables criticism of the "democratic discourse" on its own terms. If the results of immanent-critique analysis show that there is a permanent discrepancy between declared norms/ideals and reality, then the ideological nature of the democratic discourse becomes evident. I use this method to show how, under the veil of democratization, the Declaration hides its neoliberal agenda.

\section{FINDINGS}

\subsection{Substituting "Market" for "Democracy"}

Introducing the Eastern Partnership (EaP) as "a specific dimension of the European Neighbourhood Policy" whose aim is "accelerating the political association and economic integration of interested partners with the European Union," the introductory part of its Declaration asserts that 
all these "interested partners" are committed to the EaP's "guiding principles" (DECLARATION, 2013, p. 1). According to Paragraph 4 of the Declaration, this means commitment to "the principles of international law and to fundamental values, including democracy, the rule of law and the respect for human rights and fundamental freedoms, as well as to market economy, sustainable development and good governance" (DECLARATION, 2013, p. 2). The importance of "democracy" is emphasized here by its top billing in the first of two sub-lists of values, separated from each other by the conjunction "as well as": The signifiers "democracy," "rule of law," and "respect for human rights and fundamental freedoms" go first and thus appear to be more important, while "market economy," "sustainable development," and "good governance" carry less emphasis and therefore less apparent significance.

Paragraph 5 of the Declaration also highlights the importance of democracy and other top values associated with it, focusing on the necessity "to tackle the persisting challenges posed to democracy, the respect for fundamental freedoms and the rule of law" (DECLARATION, 2013, p. 2) through "strengthening the efficiency and independence of the judiciary; effectively tackling corruption; and implementing public administration reform" (DECLARATION, 2013, p. 2). In contrast to the previous paragraph, "market economy" does not appear here as a means of achieving a more advanced democratic condition. Nor does "market economy" appear in Paragraph 6, which states that the objective of the EaP is to build "a common area of shared democracy, prosperity, stability and increased interactions and exchanges" (DECLARATION, 2013, p. 2). All of these can be achieved through "cooperation" between the EU and the Eastern European countries: "The Summit participants agree that achieving closer cooperation is essential to ensure stability and prosperity on the European continent" (DECLARATION, 2013, p. 25-7).

There are two different chains of equivalence within these three introductory paragraphs of the Declaration. In Paragraph 4, "democracy" is equivalentially united with "the rule of law," "the respect for human rights and fundamental freedoms," "market economy," "sustainable development," and "good governance." In Paragraph 6, "democracy" is equivalentially united with "cooperation," "prosperity," “stability," “increased interactions," and “exchange.” In both cases, “democracy” has the same hegemonic role: It appears as the prime signifier and assumes a hegemonic representation of all other signs within the respective chains. The difference is that the second eliminates the link between "democracy" and a "market economy" in favor of other links - between "democracy" and “stability," “prosperity," “cooperation," “interactions," and “exchange.” To put it in Laclau's (2005) terms, the latter signifiers come to displace "market." Not only does this substitution equate marketization with prosperity, but it also suggests that marketization (imagined in terms of 
"prosperity," "stability," and "interaction") is an essential step on the path to "democracy," which represents hegemonically the entire equivalential chain.

This tendency to present market economy as inseparable from democracy (which is always in a hegemonic position to represent the whole of the project) is observed throughout the text. Here is another example:

Reinforced and sustainable reform efforts serve a common interest to help the Eastern European countries progress towards deep and sustainable democracies where good governance and the rule of law prevail with economies developing on market-based principles to underpin equitable and sustainable development. (DECLARATION, 2013, p. 5)

Separated from "democracy" by the subordinating conjunction "where" and preposition "with," a "market-based" economy is not declared to be a central component of the "democratic" project, yet appears indispensable nonetheless. As the collocation "market(-based) economy/principles" suggests, no other type of economy is coextensive with this "democratic" enterprise.

These examples give a sense of how the ideology of neoliberalism hides within the discourse of democratization, with the pervasive notion that "there is no alternative" (represented by the "market economy" collocation) serving as an important component of neoliberal ideology as it “installs in its subjects a belief in markets - anything else fails, is inefficient, can't be funded, won't last, can't compete in a global arena" (DEAN, 2009, p. 48). Within this bigger hegemonic construction, Deep and Comprehensive Free Trade Areas (DCFTAs) appear in the Declaration as an unproblematic part of the whole project of democratization ostensibly pursued by the EaP. Similar to the equivalence between "democracy" and "market" discussed earlier, the established relationship between "Agreements" and "DCFTAs" gives the former a hegemonic position while the latter is presented as of secondary importance, separated from "Agreements" with a comma and phrased as a possible but not predetermined outcome: "New Association Agreements, including Deep and Comprehensive Free Trade Areas (DCFTAs) between the EU and some partner countries" (DECLARATION, 2013, p. 3). DCFTAs appear in a subordinate position vis-à-vis the Agreements throughout the Declaration.

While presenting DCFTAs as an integral but not central element of the Eastern Partnership, the Declaration omits any reference to or discussion of the complexities and/or possible negative aspects of these "trading areas," preferring instead what Fairclough calls "easification [of] bureaucratic discourse" (FAIRCLOUGH, 2015B, p. 219). The Declaration closes its discourse by simply stating that DCFTAs (always presented as subordinate to the Agreements) will create, as a 
causal agent, "a wider common area of economic prosperity" (DECLARATION, 2013, p. 5), "strengthen the ability of partner countries to compete effectively in international markets" (DECLARATION, 2013, p. 15), and bring numerous other "tangible benefits to citizens in partner countries" (DECLARATION, 2013, p. 8).

It is here that the ideology of neoliberalism rears its head again: The unquestioned faith in free trade - that unfettered markets benefit everyone and bring prosperity to all - is a neoliberal fantasy that conveniently disregards permanent market failures and structural inequalities. In line with this neoliberal myth, the Declaration promises that everyone will be a winner ("tangible benefits to citizens") while also emphasizing the importance of competition ("to compete effectively in international markets"). Given that in any competition there must be losers as well as winners, the fantastic neoliberal promise made by the Declaration appears to be nothing but an ideological construct aiming to open national economies of the "interested parties" to free trade and multinational capital investments - a trend that "has become so dominant throughout the world over the past generation that even thinking through serious alternatives presents itself as a daunting task," as Jodi Dean (2009, p. 55) puts it.

In light of these realities, it is interesting that of the 26 achievements listed in the Declaration, only one addresses the issue of international financial institutions: "The Summit Participants take note of the cooperation with International Financial Institutions (IFIs) and third countries interested in donor coordination..." (DECLARATION, 2013, p. 13). Importantly, this "achievement" is the very last one listed. Given that the aforementioned institutions are the main instruments and/or driving forces behind the global neoliberal project, the modest role reserved for them in the Declaration is suggestive, especially when compared to the overemphasizing of promises related to "democracy" as equated with the "market." In line with the previous discussion of the tropological displacement of "market" in favor of "democracy," this lack of attention to IFIs invites a benign ideological interpretation: For Europe, the democratic component of the Eastern Partnership is much more important than its free-market aspects. This argument does not hold, however, if one looks more closely at the "democratic" discourse presented in the Declaration.

\subsection{Democratization as Neoliberalization}

Paragraph 7 of the Declaration states that "the participants of the Vilnius Summit take note... of the unprecedented public support for Ukraine's political association and economic integration with the EU" (DECLARATION, 2013, p. 3). However, opinion polls conducted in Ukraine on the eve of 
the Vilnius Summit showed that less than half of Ukraine's population supported the idea of European integration at that point in time (BAYSHA, 2018). The signifier "unprecedented" used in the Declaration simply masks this complicated reality, as the word can be taken to mean "outstanding," "remarkable," or "groundbreaking" - all of which hide the division within Ukraine and fail to suggest the complexity of the issue. Moreover, the "common values" mentioned in the Declaration as a condition for "interested parties" to join the project are not actually "common"; they are distinctively European, and the countries participating in the project are expected to adopt them. As the Declaration states, the Association Agreements, including DCFTAs will "facilitate comprehensive approximation towards the EU, its rules and standards" (DECLARATION, 2013, p. 3). Additionally, the Declaration explicitly links "democracy" with support for Europeanization: "The participants of the Summit highlight the significant role of local democracy and citizen participation in pursuing the goals of the Eastern Partnership" (DECLARATION, 2013, p. 21). Given the split of Ukraine's population with respect to the project, this formulation suggests the exclusion of those who do not support it.

"Democratization" is presented by the Declaration in one-directional terms, imagined as catching up with a European democratic condition set up as the norm. Rather than an arrangement by which equal partners with different cultural backgrounds would seek ways to co-exist and cooperate, the whole project is presented as "the European choice [...of...] those who seek an even closer relationship with the EU" (DECLARATION, 2013, p. 3). As is suggested by this construction, Europe appears as a gravitational center of power attracting not-so-powerful neighbors into its field. The metaphor of the "gravitational field" that I use here is invoked to reflect the constructed "naturalness" of European domination that the Declaration does not problematize, despite its ostensibly "democratic" stance.

In the "democratizing" project of the EaP as discussed in the Declaration, Europe appears not as an equal associate with others but as the "first among equals," empowered to drive the behavior of its "partners" through carrot and stick policies: "Summit participants welcome the significant financial commitment of $€ 2.5 \mathrm{bn}$ of the EU during 2010-2013 period aimed at furthering democratic development..." (DECLARATION, 2013, p. 7). In this and similar statements, Europe is presented as explicitly more powerful than other states, holding the authority to supervise them and administer discipline by an undiscussed/naturalized order of things. However, this unequal power dynamic is hidden behind the construction "summit participants welcome," which poses other participants as subjects ostensibly empowered to approve or deny EU actions. This is what Fairclough calls the manipulation of subject positions for instrumental reasons (FAIRCLOUGH, 2015b, p. 215). In light 
of the previous discussion of "democratization," imagined exclusively in terms of Europeanization, the construction "countries that made most progress in building deep and sustainable democracy" could be reworded as "countries that made most progress in appropriating EU rules and standards" or "countries that made most progress in appropriating neoliberalism." It is this substitution that reveals the inequality of power relations between the EU and its "partners" in spite of the Declaration's democratizing discourse, which also attempts to hide the neoliberal agenda of omnipresent marketization by presenting it as a secondary component of the EaP project. The construction of this document shows how, by discursive means, "neoliberalism" has been transformed into an "unquestioned analogy" of “democracy," to put it in Laclau's $(2014$, p. 22) terms.

\section{DISCUSSION}

\subsection{Under the Veil of "Democratization"}

The example provided in the previous section is only one instance of myriad discursive constructions equating neoliberalism with democracy and masking neoliberalization with the discourse of democratization. Linkages with neoliberal economic reforms were never activated in the articulations of either pro-Maidan Ukrainian politicians or their Western counterparts who supported the Maidan (BAYSHA, 2018a). The articulations of those pushing the revolution also lacked any reference to the neoliberal essence of the fight over Ukraine between bigger geopolitical players; instead, the signifier "Maidan" was inextricably linked with such signs as "liberty, democracy, and human rights," "human freedom and dignity," "the supremacy of law" and other enshrined attributes of modernity understood in Western terms. These "democratizing" discourses presented the West as a subject and Ukraine as an object of its democratizing mission (BAYSHA, 2018b). It is this "democratic" discourse that paved the way for Ukraine's neoliberal colonization, since it is simply impossible to bring democracy into a foreign society from outside: A genuinely democratic system of government presupposes that people govern their communities by themselves, without foreign intrusion. Otherwise, the project is nothing but neocolonialism hidden within the discourse of democratization.

Importantly, in all these discursive constructions that equivalentially unite neoliberalism with democracy, the latter is presented not as a product of the complex social, cultural, and philosophical transformations specific to the history of the West, but as a universal concept able to serve as a normative yardstick to measure every kind of injustice around the world. What is even 
more important with respect to the topic of this paper is that many CDA works also conceptualize "democracy" in universal terms, without acknowledging its cultural and historical specificity. It is in this sense that CDA, as I argue above, may inadvertently contribute to the naturalization of the discourse of democratization by failing to problematize its global specificity - that is, its inherent interconnection with contemporary neoliberal projects and its colonial legacy. As Ferit Güven puts it, "democracy, as a particular organization of the political sphere, becomes global, not because the idea of democracy is a universally valid one, but because the process of universalization is, both politically and intellectually, a colonial project" (GÜVEN, 2015, p. 17). The next section discusses the coloniality of the democratizing discourses in more detail.

\subsection{The Coloniality of the Democratic Imaginary}

As a starting point in any discussion of the neo-colonial potential of democratic discourse, it is important to recognize that "the same set of values and practices that produced democratic structures in Europe also produced racism and colonial holocausts" (GÜVEN, 2015, p. 61). The ideologies of racial inequality spread across the world through the works of modern European philosophers such as John Locke and Immanuel Kant (MCCARTHY, 2010). The political values of liberal justice, which the philosophers of the Enlightenment exalted, were inseparable from justifications of inequality and subjugation made by the same philosophers: While opposing the state of slavery for Europeans, Kant, Hegel, and other leading figures of the Enlightenment supported it for "savages." Hegel's philosophy of history, which positioned people in a chronological hierarchy rather than in geographical places, became an important philosophical justification for unfolding the Western colonizing enterprise across a global stage. By ascribing barbarian status to the non-Western world, Western scientists and intellectuals constructed an immediate need for the "barbarians" to be modernized, and later democratized.

Euro-Atlantic superiority, with its deep belief in Western-style progress as humankind's universal road to civilization, left a deep mark on the theories of globalization and universal democratization. Although many theorists on cosmopolitan democracy insisted that a global public sphere should be characterized by the "duty to listen to the views of others and to alternative versions of events" (GARNHAM, 1992, p. 368), they also implied the necessity of forming a global political culture based on the model of Western political liberalism. This is how Homi Bhabha comments on the issue: "A transparent norm is constituted, a norm given by the host society or dominant culture, which says that 'these other cultures are fine, but we must be able to locate them within our own grid'" 
(RUTHERFORD, 1990, p. 208). Imagining a global public sphere in line with the Western ideal of political communication as rational and inclusive (HABERMAS, 2001), many theorists of global democracy applauded cultural diversity while actually denying the possibility of cultural difference. As Joseph Stiglitz put it, "The colonial mentality - the 'white man's burden' and the presumption that they knew what was best for developing countries - persisted" (STIGLITZ, 2003, p. 24).

The application of normalized, West-centric assumptions to global problems is what decolonial thinkers call "coloniality" (QUIJANO, 2000) - the ubiquitous penetration of the colonial imaginary into all aspects of our lives, including the ways we think, communicate, and act. The discourse of democratization, uncritically applied to non-Western cultural spaces, only reproduces this colonial vision of the world that, as in colonial times, manifests itself in the discourse of the unidirectional unfolding of human history with the West presented as an avant-garde in all the aspects of development, including democratic governance (TAYLOR, 1992). Denying the complexities of historical context, this vision of the Western world also presents it as an embodiment of "normality," the measure of all other socio-cultural formations. This imaginary presupposes the division of the world into modern (civilized/modernized/democratic) and not-so-modern (barbarian/backward/nondemocratic) sociocultural formations, and reproduces the same dynamic between the West and the Rest: the former being active (developing, modernizing, and democratizing) and the latter passive (developed, modernized, and democratized) (SAID, 2003). Despite the best intentions to liberate the world from tyranny, the discourse of universal democratization only reaffirms global imperialism by naturalizing the hierarchies of global neocolonial power through "dissolving epistemic violence into apparent conceptual neutrality and terminological transparency," as Gennaro Ascione (2016, p. 319) argues. As I showed in the previous section, coloniality, as it reaffirms global imperialism through the neoliberalization of former colonies, also allows neoliberalism to spread over the rest of the world not previously colonized by the West.

\subsection{The Eradication of Otherness in the Name of Democracy}

There is another very important reason to recognize the fundamental role of democratization discourse in global neoliberalization: In addition to its other effects, this discourse also transforms those who protest against it - those who may rightfully be termed enemies of neoliberalism - into enemies of democracy. In the case of post-Soviet conversion to neoliberalism in the 1990s, the most obvious illustration of this was Boris Yeltsin's order for tanks to attack the Russian parliament building and shell it into ruins rather than permit legislators to check the unregulated marketization 
of Russia. In official discourse, this was presented as "democratization" (SNYDER, 2018, p. 44). In 2014 Ukraine, the tendency to outlaw the "enemies of the democratic revolution" manifested itself in uniting all the opponents of the Maidan in one equivalential chain in which the signifier "separatists" and later "terrorists" came to denote the impossible totality of those Ukrainians who, for various reasons, did not support the revolution (BAYSHA, 2017). Instead of negotiations, which the antiMaidan protesters in the East of Ukraine had anticipated and counted on, an "anti-terrorist" military operation was launched by the post-Maidan Ukrainian government. Thousands of people were killed, injured, internally displaced or forced to flee the country.

One may argue that the examples I have provided are outliers. Güven would disagree. For him, democracy always "protects itself undemocratically by banning, excluding, and censoring political movements that are 'undemocratic'" (GÜVEN, 2015, p. 12). If there is an opposition to a democratic movement, he argues, "we either try to transform this antagonism to agonism or render it irrational, radical, or terroristic" (GÜVEN, 2015, p. 12). It is noteworthy that these repressions are always perpetrated in the name of freedom, democracy, and security of "the people of good will" that is, those sharing common "democratic" values. Since, as shown earlier, in the course of neoliberal transformations, "democracy" comes to be equivalentially united with "neoliberalism," those rejecting the latter are likely to be cast as "enemies" of the former.

In support of his point, Güven invokes Chantal Mouffe's theory of agonism, in which she defines the adversary as "an enemy, but a legitimate enemy, one with whom we have some common ground because we have a shared adhesion to the ethico-political principles of liberal democracy" (GÜVEN, 2015, p. 36). What does it mean when opponents are not considered "legitimate"? Can we infer that these "illegitimate" opponents "do not even belong to humanity?" Güven (2015, p. 36) wonders. As soon as "democracy" is linked to "human civilization," the enemies of neoliberalism (equated to the enemies of democracy) can be transformed into the enemies of "humanity." Given the colonial legacy of the discourse of civilization and humanitarianism, it is not surprising that the forces standing on the side of "humanity" usually reside in the Western hemisphere and have white skin.

The tendency of "democracy" (as inextricably linked to neoliberalism/neocolonialism) to fight against its "non-democratic opponents" by defining them as "enemies of humanity" finds its most succinct expression in former U.S. President George W. Bush's infamous dictum, "You are either with us or against us." The statement is remarkable not only because it simplifies the complexity of global social reality to the extreme but also because its logic is in line with that of democratic theorizing: It suggests that "liberal democracy does not mean that 'we' will give up our 
identity, but 'they' are going to become just like 'us"' (GÜVEN, 2015, p. 36). This is a typical conceptualization of the political from the European-colonialist perspective, and it reveals another negative characteristic of the discourse of democratization - its tendency to close the political imaginary against anything other than simplified, recognizable "democratic forms."

\subsection{Establishing the Limits of the Thinkable: The Closure of Discourse}

In order to acknowledge this tendency, it is enough to imagine "that certain nations might elect governments that might be in conflict with the 'original' Western democracies," Güven (2015, p. 57) claims. For him,

This is one of the fundamental problems of democratic theory that has always been a major contradiction. Is it possible to democratically choose nondemocracy or does democracy always inevitably choose itself? In certain countries, like Turkey, democratically elected religious parties present a dilemma both for themselves and for democracy. Their worldview is fundamentally at odds with democracy. Yet nobody wants to leave them simply outside of democracy (underground so to speak), because thereby they become more dangerous. Yet they can participate in democracy by partially becoming other than themselves. Hence, the myth of diversity in democracy becomes unveiled. Democracy appears to allow a certain kind of diversity, while in its logic it also undermines the very idea of difference and diversity. Democratic structures can only deal with alternatives to the extent that they consider the latter only as "nondemocratic." The logic of democracy therefore is one of the affirmation and production of the sameness over difference. (GÜVEN, 2015, p. 86)

It is here that we come to another problem of the discourse of democratization: its tendency to homogenize the world, to simplify cultural diversity, and, through establishing the limits of the "thinkable," to reduce the political to the democratic, thereby closing down the imagination.

According to Güven, the main problem stemming from this tendency to reduce the political to the democratic is the colonization of the future - what he calls "the tyranny of democratic discourse" (p. xiii), which does not allow for imagining any other forms of human coexistence. "Why is it that as soon as we open our mouths we promise democracy?" Güven wonders (GÜVEN, 2015, p. 3). The citations from the works of critical-discourse scholars provided at the beginning of this paper illustrate the legitimacy of his concern. As is evident from them, any injustice defined as a "democratic deficit" tends to be evaluated against an ideal democratic form (deliberative, radical, etc.) that does not exist and has never existed. This is what Jacques Derrida called "democracy-tocome" (DERRIDA, 2002, p. 105) - a promise of a better democratic condition in the future, but without any vision beyond traditional liberal conceptions of democracy. Through this forever- 
unrealized promise, "democracy established a perpetual hegemony over the future as well as the present and the past" (GÜVEN, 2015, p. 13). Regulating the future while pretending not to, it produces uniformity in political thinking and blackmails critics by asking: "What else? Is there an alternative?" (GÜVEN, 2015, p. 34). It is this closure of imagination that justifies any injustice in the name of a future justice.

\section{CONCLUSIONS}

The arguments presented in this paper suggest a serious consideration of the following questions: If the normative imaginary that has enabled democratic theorizing also enables global neocolonialism in the form of neoliberalism, is there a need for alternative viewpoints in order to measure and address the present imaginary's negative consequences? In the absence of such alternatives, will dependent societies, trying to govern themselves according to the "universal" rules of democracy established by global colonial powers, only aggravate their colonial condition? Does it make any sense to go on with the uncritical employment of the discourse of democratization as an opposite to neoliberalism if the former is a continuation of the infamous "mission civilisatrice" - if it serves as a tool of neoliberal/neocolonial subjugation, and if it perpetuates the same dynamics of "superiority vs. inferiority" of the colonizer and the colonized? How would "democratic" globalization differ from "global coloniality" if it is informed by the same colonial imaginary that reaffirms Eurocentrism?

These questions are too important to be simply ignored, and CDA can play a key role in advancing this line of inquiry because its aims, as stated by Fairclough, are "to respond to the great issues and problems of the day" and to promote "a better understanding of these [neoliberal] changes and their effects" so as to "resist them and develop alternatives" (FAIRCLOUGH, 2003, p. 203). If the tendency to promote neoliberalism under the veil of democratization, as discussed in this paper, is one of the "great issues" of our day, we need to develop a better understanding of the role played by the discourse of democratization in the global hegemony of the neoliberal imaginary. What if neoliberal marketization does require the "democratization of discourse," as Fairclough (1992) once suggested? Without addressing this issue, critical scholars are at risk of perpetuating neoliberalism instead of deconstructing and subverting it. 


\section{REFERENCES}

ASCIONE, G. Decolonizing the 'global': the coloniality of method and the problem of the unit of analysis. Cultural sociology, v. 10, n. 3, p. 1-18, 2016.

BAYSHA, O. The mythologies of capitalism and the end of the Soviet project. Lanham, MD: Lexington, 2014.

BAYSHA, O. In the name of national security: articulating ethno-political struggles as terrorism. Journal of multicultural discourses, v. 14, n. 4, p. 332-48, 2017.

BAYSHA, O. Miscommunicating social change: lessons from Russia and Ukraine. Lanham, MD: Lexington, 2018a.

BAYSHA, O. Synecdoche that kills: how Barack Obama and Vladimir Putin constructed different Ukraines for different ends. International Communication Gazette, v. 80, n. 3, p. 230-49, 2018 b.

BOYD-BARRETT, J. O. Western mainstream media and the Ukraine crisis: a study in conflict propaganda. London: Routledge, 2017.

BRUCE, I. Resisting neoliberalism through political and social critique: the Guardian column of Polly Toynbee. Discourse, Context \& Media, v. 10, p. 45-52, 2015

DEAN, J. Democracy and other neoliberal fantasies. Durham \& London: Duke University Press, 2009.

DECLARATION. Joint declaration of the Eastern Partnership Summit. Council of the European Union, 29 November, 2013. Available at: https://www.consilium.europa.eu/media/31799/2013_eap11-28-joint-declaration.pdf. Accessed on: 29 May, 2020.

DERRIDA, J. Who's afraid of philosophy: right to philosophy. Stanford, CA: Stanford University Press, 2002.

FAIRCLOUGH, N. Discourse and social change. Cambridge: Polity Press, 1992.

FAIRCLOUGH, N. Media discourse. London, New York: Edward Arnold, 1995.

FAIRCLOUGH, N. Analyzing discourse: textual analysis for social research. New York: Routledge, 2003.

FAIRCLOUGH, N. Language and globalization. New York: Routledge, 2006.

FAIRCLOUGH, N. Critical discourse analysis: the critical study of language. New York: Routledge, 2013.

FAIRCLOUGH, N. A dialectical-relational approach to critical-discourse analysis in social research. In: WODAK, R.; MEYER, M. (org.). Methods of critical discourse studies. London: SAGE, 2015a.

FAIRCLOUGH, N. Language and power. New York: Routledge, 2015b. 
GARNHAM, N. The media and the public sphere. In: CALHOUN, C. (org.). Habermas and the public sphere. Cambridge, MA: MIT Press, 1992.

GUARDINO, M. Neoliberal populism as hegemony: a historical-ideological analysis of US economic policy discourse. Critical Discourse Studies, v. 15, n. 5, p. 444-62, 2018.

GÜVEN, F. Decolonizing democracy: intersections of philosophy and postcolonial theory. Lanham, MD: Lexington, 2015.

HABERMAS, J. The postnational constellation: political essays. Cambridge, MA: MIT Press, 2001.

JÄGER, S.; MAIER, F. Analysing discourses and dispositives: a foucauldian approach to theory and methodology. In: WODAK, R.; MEYER, M. (eds.). Methods of critical discourse studies London: SAGE, 2015.

JUSKA, A.; WOOLFSON, C. The moral discourses of 'post-crisis' neoliberalism: a case study of Lithuania’s Labour Code reform. Critical Discourse Studies, v. 14, n. 2, p. 132-49, 2017.

LACLAU, E. On populist reason. New York: Verso, 2005.

LACLAU, E. The rhetorical foundations of society. New York: Verso, 2014.

MCCARTHY, T. Race, empire, and the idea of human development. Cambridge, MA: Cambridge University Press, 2010.

PHILIPS, L.; JØRGENSEN, M. Discourse analysis as theory and method. London: SAGE, 2002.

POWER, M. et al., Reasonable people vs. the sinister fringe: Interrogating the framing of Ireland's water charge protestors through the media politics of dissent. Critical Discourse Studies, v. 13, n. 3, p. 261-77, 2016.

RUTHERFORD, J. The third place: interview with Homi Bhabha. In: RUTHERFORD, J. (eds.). Identity, community, culture, difference. London: Lawrence \& Wishart. 1990.

SAKWA, R. Frontline Ukraine: crisis in borderlands. London; New York: I. B. Tauris, 2015.

SNYDER, T. The road to unfreedom: Russia, Europe, America. New York: Tim Duggan Books, 2018.

QUIJANO, A. Coloniality of power and Eurocentrism in Latin America. International sociology, v. 15 , n. 2, p. 215-32, 2000.

SAID, E. W. Orientalism. NY: Pantheon Books, 1979.

STEGER, M. Globalism: Market ideology meets terrorism. Lanham: Rowman and Littlefield, 2005.

STIGLITZ, J. E. Globalization and its discontents. New York; London: W.W. Norton \& Company, 2003.

TAYLOR, C. Sources of the self: the making of the modern identity. Cambridge, MA: Harvard University Press, 1992. 
VAN DIJK, T. A. Critical discourse studies: a sociocognitive approach. In: WODAK, R.; MEYER, M. (eds.). Methods of critical discourse studies. London: SAGE, 2015. p. 62-85.

WODAK, R.; MEYER, M. Critical discourse studies: history, agenda, theory and methodology. In WODAK, R.; MEYER, M. (ed.) Methods of critical discourse studies. London: SAGE, 2015., p. 122.

YURCHENKO, Y. Ukraine and the empire of capital: From marketization to armed conflict. London: Pluto Press, 2018. 